DE92 015292

\title{
GENERATION AND MOBILITY OF RADON IN SOIL
}

\section{ANNUAL REPORT}

Research Objectives:

1. To determine the processes that cause large seasonal and short-term changes in the radon ( $R n$ ) content of soll gases, and to develop methods of predicting and modeling these variations.

2. To evaluate the relation of $R n$ emanation coefficients to form of radium ( $R a$ ) and other U-series decay products, particularly the role of $R$ a in organic matter and Fe-oxides.

3. To evaluate the conditions in which convection of gas in soil and bedrock may affect soil gas radon availability in houses.

4. To collaborate with other DOE researchers on evaluation of Rn flux into houses, using our well characterized soll sites.

\section{Method:}

A set of 13 sites representing several parent materials, climatic regimes, and drainage conditions in eastern and central U.S. (PA, NY, NC, $T N$, IL) have been investigated in detail, and an additional site will be investigated in New Mexico with $D r$. Steven Shery's group. A complete soil description plus measurements of radon and thoron in soil gas, and radium, uranium, thorium, air permeability, diffusion coefficient and emanation coefficients of soils have been obtained at each of the eastern sites. The observed results for Rn have been compared with models of Rn generation and transport. Follow-up investigations to evaluate selected discrepancies are currently underway. The possibility of thermally driven air convection is being studied at two sites considered favorable for this phenomenon. In addition, a collaboration on radon transport at a building site is underway with Dr. Donald Thomas of the University of Hawail.

\section{Relevance to Reduction of Risk Uncertainties:}

The application of computer models for estimating radon exposure in houses and the effects of mitigation techniques requires complete understanding of the physical and chemical phenomena involving radon and its precursors in soils, and accurate input values for properties such as emanation coefficients, diffusiun coefficients, permeability, radium concentration and other variables. The intent of this research is to investigate processes and properties s) that models and generalizations from them will be valid.

\section{Scientific Accomplishments:}

During the past year, effort has been concentrated on interpreting and writing up data on $R a, U$, and $T h$. In the area of radon in soll gas, progress has been slow because no Graduate Assistant was available in Fall 1990 due to budget constraints, and a new Graduate Assistant, Hyomin Lee, started in January 1991 but is still developing knowledge and techniques. 
1. Radium, the immediate parent of radon, exhibits relatively high mobility in soil-forming processes, as might be expected from its similarities to Ca and other alkaline earth elements. Ash of vegetation typical of each site has average Ra activity about equal to the soli, and 2.7 times its parent uranium; some vegetation ashes have Ra contents 1808 of the underlying soll.

2. In the soil, a high proportion of the Ra occurs in the organic fraction (Figure 1 ), which has an average Ra/U activity ratio of about 25 ( $i$.e., Ra in this organic matter is unsupported). In contrast, soll minerals residual from bedrock are significantly depleted in $R a$ relative to $U$ at most sites. Because of enrichment of $R a$ relative to $U$ in organic-rich surface soils, the content of $U$ in solls is not necessarily a giod guide to the content of $R a$ (and $R n$ ), and gammactivity of $21{ }^{3 i}$ at the surface may not be representative of deeper soils.

Calculations show that although Ra flux from vegetation is adequate to supply the Ra in organfic matter of the $A$ horizon, the Ra in organic matter of deeper horizons carnot be maintained by flux from vegetation. A major part is apparently transferred directly from soil solutions into already dead organic matter, or is assimilated and retained in the roots without being cycled through above-ground parts of plants.

3. Multiple regression of radon emanation for 26 soils vs. percentages of radium in the organic, Fe-oxide, sand, silt and clay components shows that about 658 of the emanated Rn results from decay of $2{ }^{2} \mathrm{Ra}$ in organic matter, with an emanation coefficient of about 648 (Figure 2). Based on both the regreisions and experiments on extracted samples, most of the remaining Rn emanates from silt and clay grains, with an emanation coefficient of about 228 .

The Ra enrichment in the organic fraction and the high contribution of organic matter to Rn emanation imply that construction or mitigation practices affecting soil organic matter, or regional differences in organic matter of soils, may have a marked affect on Rn concentrations in homes and in soil gas. Backfilling against wall using organic-poor soil (i.e., with low emanation coefficient) should tend to minimize Rn in buildings.

4. Emanation of thoron $\left(220_{R n}\right)$ has also been measured on 62 soil samples. About half the thoron emanation is from silt-and clay-sized particles, and about half is from Fe-oxide coating on soli particles. The host for thoron differs from radon ( $22 \mathrm{Rn}$ ) because of the short half life of thoron precursors, so that long-lived ${ }^{2} 32 \mathrm{Th}$ is the effective parent. Based on this data, the relative emanation of radon and thoron way differ considerably in soils of different types and regions.

5. In many young solis developed on glacial deposits, activity of $R a$ in silt and clay after extraction of organic matter and Fe-oxides exceeds $U$, apparently because of rapid leaching of $U$ in post-glacial time sut retention of $23 \mathrm{Th}$, the parent of Ra.

6. In well developed, mature soil profiles, especially in southeastern U.S., U and Th are markedly depleted from the 
surface horizons, and in some, these elements are enriched in the B horizon (Figures 3,4 ). The depletion and enrichments are commonly 508 of the value at depth, and in one case by up to five-fold. Depletion of $U$ and $T h$ from the surface horizons apparently occurs by leaching and washing out of fines, combined with a relatively limited cycling by vegetation. In contrast, young solis show little variability in $U$ and Th within a profile (Figure 5 ).

7. On average, 158 of the $U$ and 318 of the Th are incorporated in Fe-oxides, with very little occurring in organic or exchangeable form (Figures $3-5$ ). The Rajn Fe-oxides is inferred to be derived largely by decay of 23 Th and 234
incorporated in the Fe-oxides. This conclusion is substantiated by experimental data showing that little Ra is adsorbed on Fe oxides at $\mathrm{pH}$ values less than about 6.5 (the solls have $\mathrm{pH} s$ of $3.5-5.5)$.

8. In extremely wet soils, we observe unusually low values of Rn in soll gas. Mathematical relations have been developed for two phenomena that seem to explain this observation: decay of Rn during slow diffusion in water-filled pores, and downward diffusion of Rn toward bedrock. These relations should be incorporated into computer models for $R n$ in solls adjacent to houses. Also, note that changes in soil moisture status may have major effects on radon levels in homes.

9. Surface barrier radon detectors loaned to us by DOE Radon Contractor Dr. Donald Thomas (Univ. of Hawail) have been used to measure short-term variability in $R n$ at one of our sites.

Variations by a factor of about $x 4$ over periods of a few days are recorded, with abrupt changes related to rainfall or melting events (Figure 6). Significant diurnal effects are also evident in data from spring (Figure 7), but barometric effects are not obvious.

10. A review of the literature on thermally driven convection has turned up several interesting papers. Sturm and Johnson (J. Geoph. Res. 96:11657, 1991) demonstrate convection of air in snow near Fairbanks, Alaska. This convectica occurs under conditions that would not allow convection under the widely accepted Rayleigh criterion. Sturm and Johnson_show that under natural conditions where the upper and lower boundaries of the material are not horizontal planes but are sloping or irregular surfaces, convection is expected if temperature decreases upward. This conclusion is supported by experiments and theoretical relations developed by Bories and Combarnous (J. Fluid Mech. 57:63, 1973) showing that sloping planar porous bodies should convect if their lower surfaces are hotter than their upper surfaces. We have not found any studies documenting this phenomenon in solls, but it seems likely to occur.

\section{PLAITS FOR THE COMING YEAR}

Three areas of investigation will be pursued in the $1992-3$ period: Temporal variability of soll-gas radon ( $\frac{1}{2} g_{\text {luding }}$ al convection in soils), geochemistry of $230 \mathrm{Th}$ and $23 \mathrm{~T}_{\mathrm{U}}$, and collaboration with Dr. Donald Thomas on radon behavior prior to and after construction of a home on a monitored site. 
Temporal Variability

The extreme inter-time lows in soil gas radon will be further investigated in order to develop additional evidence that the moisture effects and bedrock effects noted above are the inajor cause of these variations, and to identify any additional causes such as convection. Periodic measurements of radon, molsture, temperature, porosity distribution and other soil and weather characteristics were started at sites $14-80$ and 14.83 in January 1991, and will be continued during the coming winter. In addition, the Alphanuclear detectors on loan from Don Thomas will be used to investigate short-term variability (hours) at these sites.

In order to extend our model of seasonal variation of radon to different climates, arrangements are underway to measure soilgas radon, moisture and temperature at a site near socorro, NM, with the collaboration of Steven Schery and Piotr Wasiolek. We expect the variations in this site to be smaller than those observed in the setter solls of eastern U.S., but should be detectable. Schery and Waslolek have made several suggestions for improved methods of measurement.

Air Convection

Based on the literature review discussed above, a preferred location for thermally driven air convection in solis is in relatively permeable material on moderately steep slopes. We have tentatively identified two such sites to test this phenomenon, one a talus slope near spruce Creek, PA, and the other in a very sandy soll near state College. Local variations $\therefore$ temperature gradients appear to be a sensitive method of detecting convection, so the sites will be instrumented during the current $y \in a r$ with an array of thermocouples and a recording system. Ports for extracting gas samples, and equipment for collecting data on wind speed and direction and on air temperature will also be established during the current iudget year. Measurements will continue during 1992 . A computer model will also be developed to investigate controls on soll alr $\{30$ Th and 234 in sol1 Profiles

The results to date on behavior of radium, as discussed above, clearly show that some Ra variability is probably due to fractionation of its longer-lived parents during soli-forming processes. For example, in the clay and silt fractions in the deeper parts of soil profiles developed on glacial materials, and in the total samples of $B$ and $C$ horizon from some of these ${ }$
profiles, Ra activity exceeds U, and we hypothesize that 238 and 230 files, Ra activity exceeds $U$, and we hypothesize that $238 \mathrm{U}$
$\mathrm{U}$ have been leached but unsupported $230 \mathrm{Th}\left(\mathrm{t}_{1} / 280,000 \mathrm{yr}\right)$ remains to generate the elevated Ra values. We plan to analyze the existing samples of total soil and selectively extracted fractions from the profiles in order to test this and similar hypotheses. An experimenf, to confirm the organic origin of the emanated $R$ in by exchanging ${ }^{24} \mathrm{Ra}$ for ${ }^{226} \mathrm{Ra}$ will also be conducted. Rn Transnort into Houses

During October 1991 we will install Alphanuclear detectors at a building site in state College in collaboration with Dr. Don Thomas of the University of Hawail. We will monitor these sites 
for a year, after which the developer has indicated he will build a home on the property. The monitoring will continue for another year to examine the effects of building on the Rn distribution at the site.

\section{PUBLICATIONS RESULTING FROM THE PROJECT}

Smith, R.C., Reilly, M.A., Rose, A.W., Barnes, J.W., Radon: A profound case, Pennsylvania Geology, v. 18(2), p.2-7, 1987.

Cecil, L.D., Smith, R.C., Reilly, M.A., Rose, A.W., Radium-228 and Radium-226 in Groundwater of the Chickles Formation, Southeastern Pennsylvania, in Radon. Radium and Other Radioactivity in Groundwater, Proc. of National Water Well Assoc. Conf., ed. by B. Graves, Lewis Publ., P. 437-447, 1987.

Rose, A.W., Washington, J.W., Greeman, D.J., Variability of Radon with Depth and Season in a Central Pennsylvania Soil Developed on Limestone: Northeastern Environmental Science, 7:35-39, 1988 .

Greeman, D.J., Rose, A.W. and Jester, W.A., Form and Behavior of Radium, Uranium and Thorium in Central Pennsylvania Soils

Developed from Dolomite, Geophysical Res. Lett., 17:833-836, 1990 .

Washington, J.W., Rose, A.W., Regional and Temporal Relations of Radon in Soil Gas to Soll Temperature and Moisture, Geophysical Res. Lett, $17: 829-832,1990$.

Rose, A.W., Hutter, A.R., Washington, J.W., Sampling Variability of Radon in Soil Gases, J.Geochemical Exploration, 38:173-191, 1990 .

Rose, A.W., Ciolkosz, E.J., and Washington, J.W., Effects of Regional and Seasonal Variations in Soil Molsture and Temperature on Soil Gas Radon, in The 1990 Int. Symp. on Radon and Radon Reduction Technology, v.III, Rept. EPA/600/9-90/005c, Paper C-IV5,1990 .

Rose, A.W., Jester, A.W. anbd Ford, B.C., Radioactive Elements in Pennsylvania Waters, in Environmental Radon: Occurrence, Control and Health Hazards, ed. by S.K. Majumdar, R.F. Schmalz and E.W. M1ller, Penna. Acad. Sclence, p. 91-109, 1990.

Rose, A.W., Washington, J.W. and Greeman, D.J, Geology and Geochemistry of Radon Occurrence, in Environmental Radon: Occurrence, Control and Health Hazards, ed. by S.K. Majumdar, R.F. Schmalz and E.W. Miller, Penna. Acad. Science, P. 64-77, 1990 .

Washington, J.W., Rose, A.W., Temporal Variability of Radon Concentration in the Interstitial Gas of Solls in Pennsylvania. Manuscript resubmitted to J. Geophysical Res. after revisions based on inftal review. 
Rose, A.W., The Radon Hazard, invited manuscript, The Geology of Pennsylvania, ed. by C.R. Schultz, to be publ. by PA. Geol. Survey.

Washington, J.W., Rose, A.W., Coefficients of air permeability and diffusion through soil profiles: Manuscript.

\section{Published Abstracts}

Hutter, A.R., Rose, A.W., Radon Variability in Soil Gases over Fracture Traces in Limestones, Central Pennsylvania, Geol. Soc. of Amer. Abst, with Prog, 19:90, 1987.

Washington, J.W., Rose, A.W., Controls of Seasonal Variability of Radon Content of Soil Gas, Geol. Soc. Amer. Abst with Prog, $20: A 354,1988$.

Greeman, D.J., and Rose, A.W., Abundance and occurrence of $U$, Th and $R a$ in Pennsylvania and Georgiz: Solls: Geol. Soc. Amer. Abst. with Prog., 20:A336, 1988 .

Marvin, R.K., Parizek, R.R., and Rose, A.W., Effects of water table fluctuations on Radon-222 Concentration and Mobility in overlying Soll, Geol. Soc. Amer. Abst, with Prog., 20:A354, 1988.

Rose, A.W. and Washington, J.W., Controls of Seasonal Variability in Radon Content of Soil Gas, Geol. Soc. Amer. Abst. with Prog., 1:1:63, 1989 .

Washington, J.W., Rose, A.W., Greeman, D.J., Effects of Inhomogeneity of Soll properties on Radon Transport in Soll Gases, EOS, 70:497, 1989.

lose, A.W., Hutter, A.R., Washington, J.W., Sampling Variability (f Radon in Soll Gases, XIII Int Geochemical Exploration Symp., 1. Lo de Janeiro, 1989 (Abst.).

Wishington, J.W., Rose, A.W., Effects of Variation in Soil T.mperature and Moisture on Radon in Soil Gases, Geol. Soc. Amer Alst. with Prog., 21:A145, 1989.

Greman, D.J., Washington, J.W. and Rose, A.W., Measurement and Pr adiction or Geologic Radon: Some Considerations, Geol. Soc. Amar. Abst, with Prog., 23:15, 1991 .

Greeman, D.J., Rose, A.W., and Jester, W.A., Evaluation of Radon Precursors and Radon Production in Major Soll Types for the NE U.S., EOS, 71:647, 1990.

Gref:man, D.J., Rose, A.W. and Jester, W.A., Geochemical Dynamics of $\mathrm{R}$ adon Precursors in Eastern U.S. Solls, Geol. Soc, of Amer. Abst, with Prog. 22:A247, 1990 . 
Greeman, D.J. and Rose, A.W., Effects of Pedogenesis on the Mobility of Radon Precursors in Eastern U.S. Solls, Geol. Soc. Amer. Abst, with Prog. 23(1):38, 1991 .

Greeman, D.J., Rose, A.W., and Washington, J.W., The prediction and measurement of geologic radon: Some considerations, Geol. Soc. Amer. Abst, with Prog. 23(3):15, 1991.

Greeman, D.J., and Rose, A.W., Geochemical controls on radon emanation in soils: Importance of organic radium, Geol. Soc. Amer. San Diego meeting. Oct. 1991.

\section{Theses}

Hutter, A.R., Radon Variability in Soll Gas over Fracture Traces: M.S. Thesis, Penn State University, 156 p., 1987.

Marvin, R.K., Effects of Water Table Fluctuation and Meteorological Parameters on Radon-222 Concentration and Mobility in Soll, M.S. Thesis, Penn State University, 252. p., 1939.

Washington, J. W., Radon Generation and Transport in Solls, $\mathrm{Ph}$. D. Thesis, Penn State University, 207 p., 1991.

Greeman, D.J., The Geochemistry of Uranium, Thorium and Radium in Northeastern United States Soils, Ph.D. thesis to be defended october 1991 .

\section{DISCLAIMER}

This report was prepared as an account of work sponsored by an agency of the United States Government. Neither the United States Government nor any agency thereof, nor any of their employees, makes any warranty, express or implied, or assumes any legal liability or responsibility for the accuracy, completeness, or usefulness of any information, apparatus, product, or process disclosed, or represents that its use would not infringe privately owned rights. Reference herein to any specific commercial product, process, or service by trade name, trademark, manufacturer, or otherwise does not necessarily constitute or imply its endorsement, recommendation, or favoring by the United States Government or any agency thereof. The views and opinions of authors expressed herein do not necessarily state or reflect those of the United States Government or any agency thereof. 


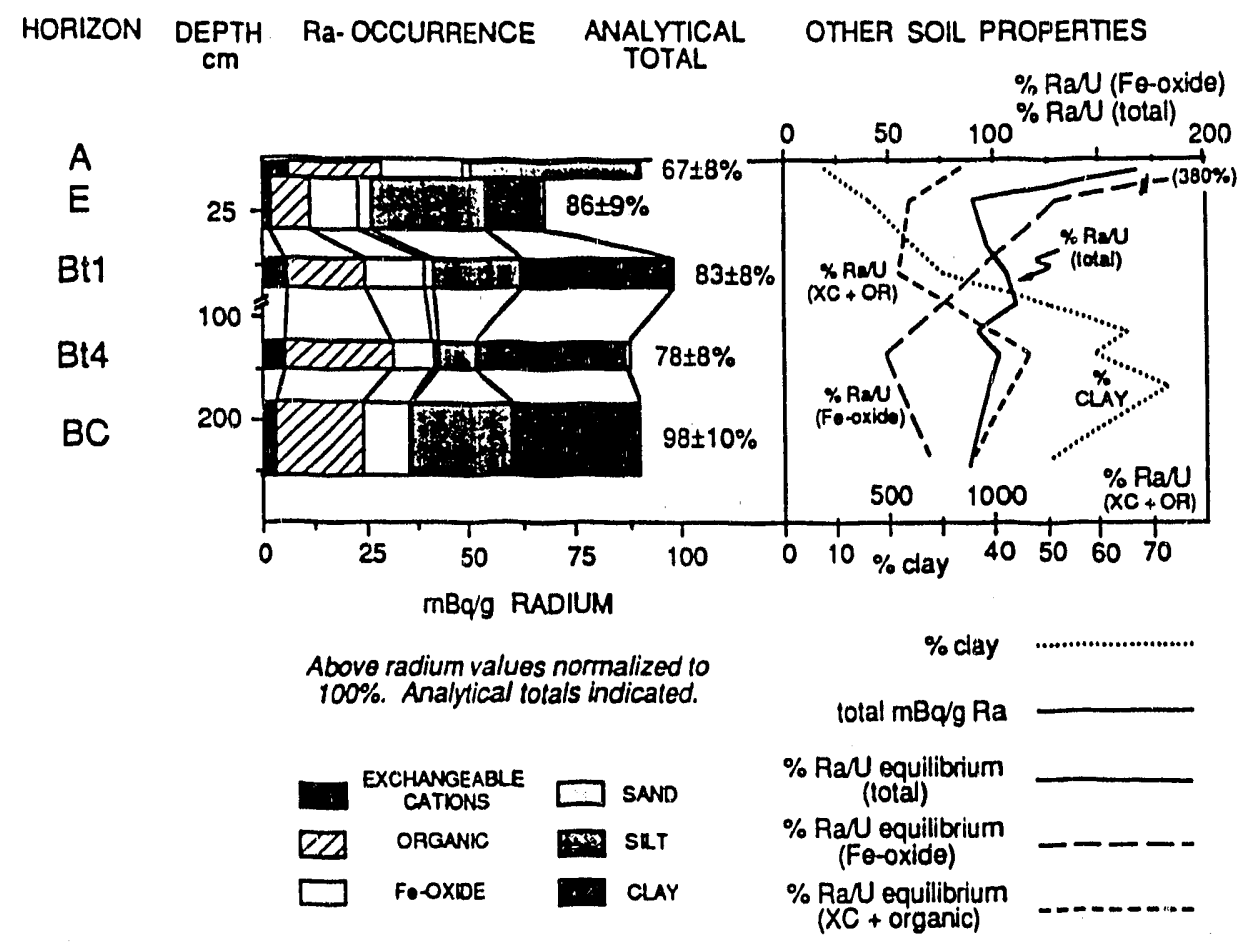

Form of radium vs. depth in a well-drained, dolostone-derived soil at site 14-80. Note $2 X$ scale first $70 \mathrm{~cm}$. Abbreviations: $X C=$ exchangeable cations; $O R=$ organics. Analytical error: Ra $= \pm 6-18 \% ;$ day $= \pm 5 \%$. All anahytical errors \pm 10 .

HDRIZON DEPTH Ra-OCCURPENCE ANALYTICAL OTHER SOIL PROPERTIES

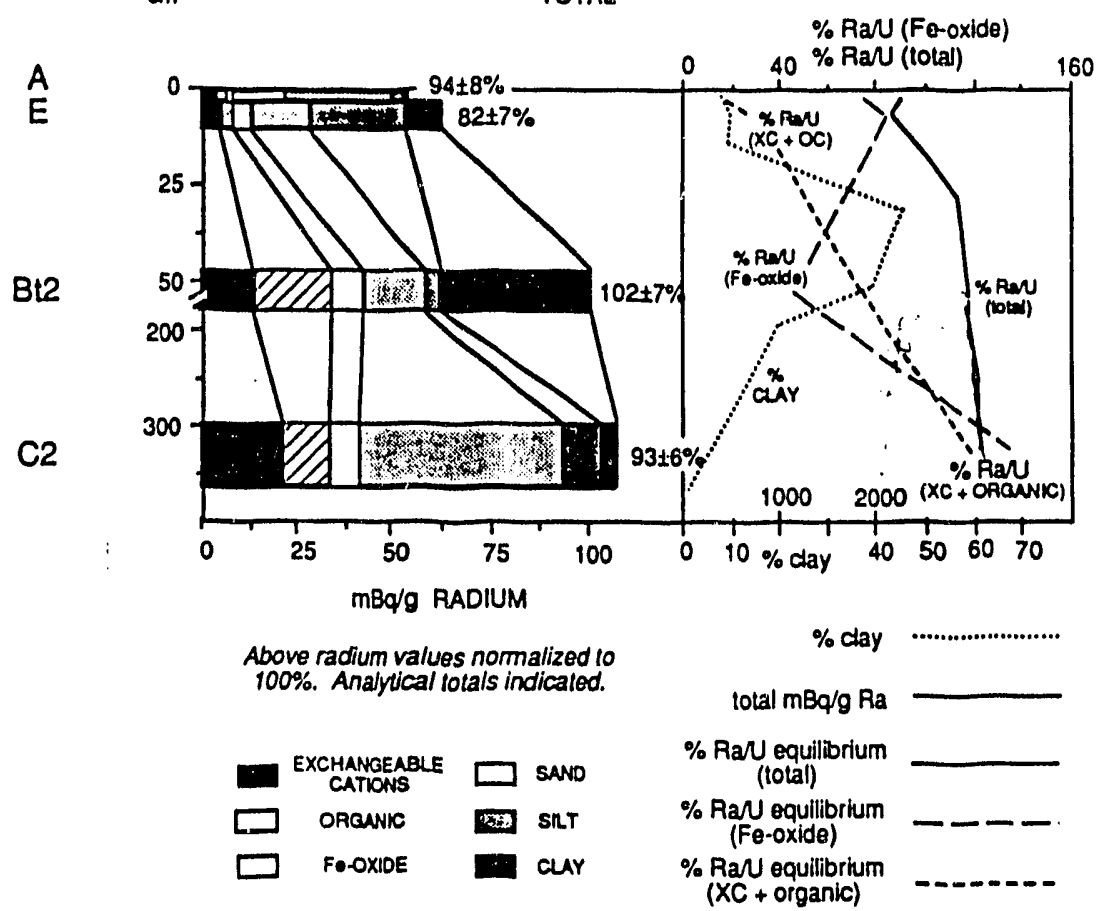

Form of radium and other sol properties in a granite-derived soil at site NC.1. Nole $4 X$ scale at begining of depth scale. Abbreviations: $X C=$ exchangeable cations; $O R=$ organics. Analytical error: Ra $= \pm 6-18 \%$; clay $= \pm 5 \%$. Analytical errors quoled at \pm 10 . 


\section{Radon Emanation vs. Organic Radium}

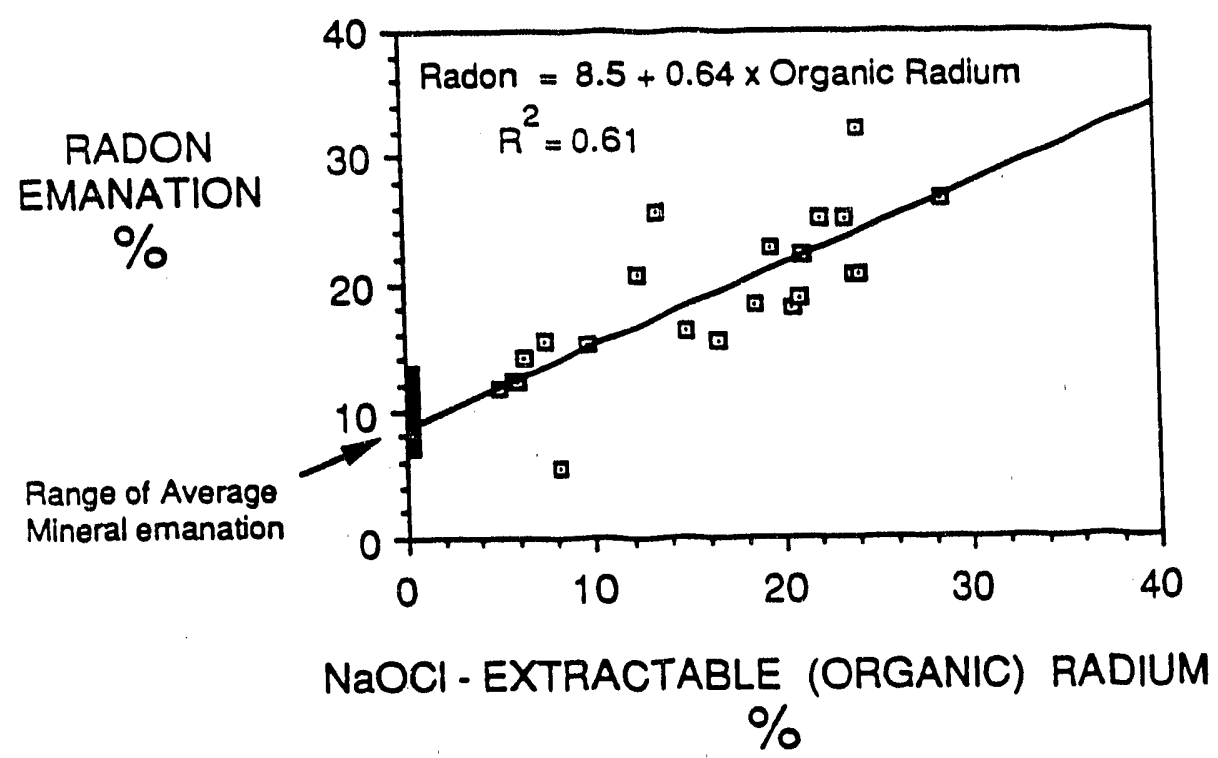

Organic radium with an emanation coefficient of about $64 \%$ for seventeen samples of soil from NY, PA, NC, and IL. Intercept of $8.5 \%$ Rn emanation (non-organic emanation) is within one standard-deviation of average "mineral" emanation. One-sigma analytical error $\pm 15 \%$.

Figure 2. Radon emanation coefficient vs. "organic radium" 


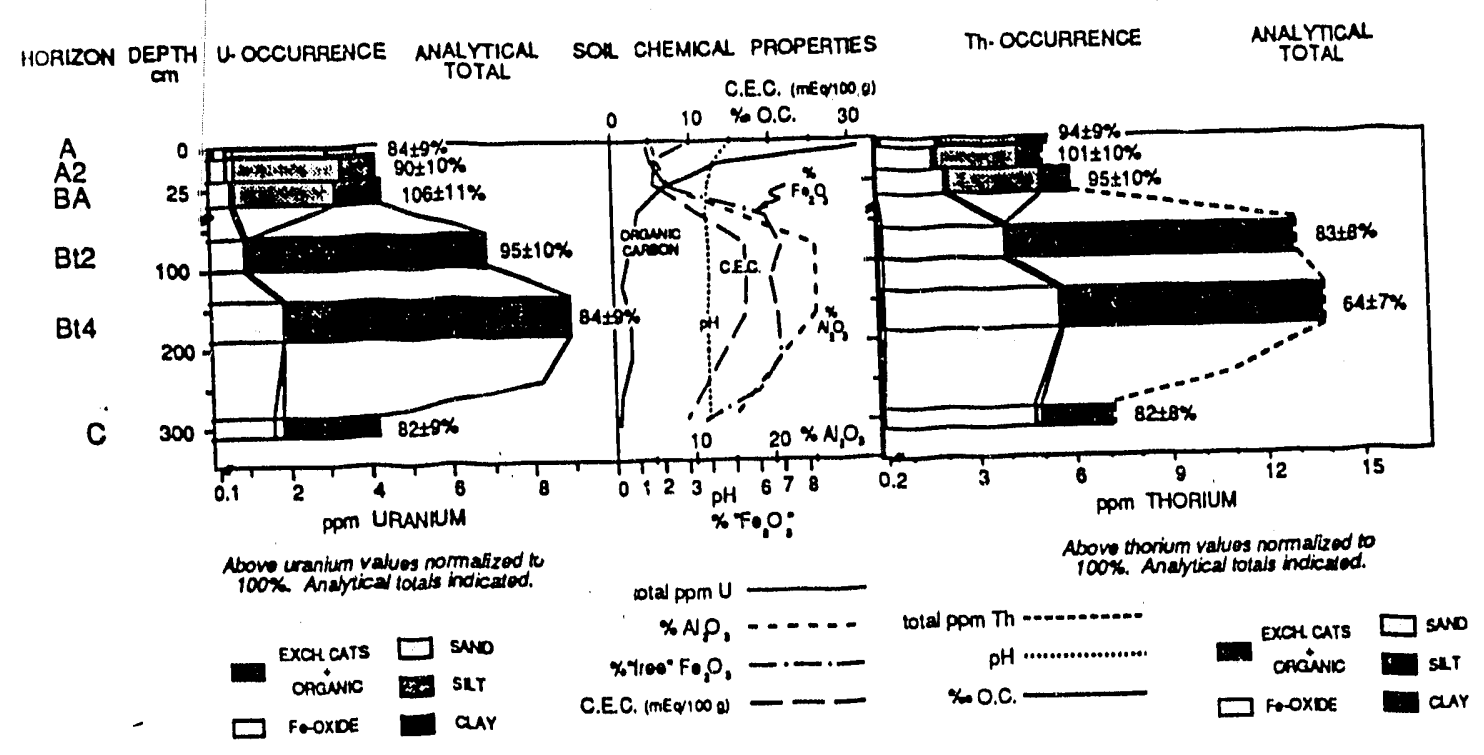

Form dU Th, and other soil properties vs, depth in soll at site TN.1. Abbroviations: O.C. - Organic

Form d C. Th, and a cation exchange capacity; EX. CATONS - oxchangeable calions; mEq - milloquivalents
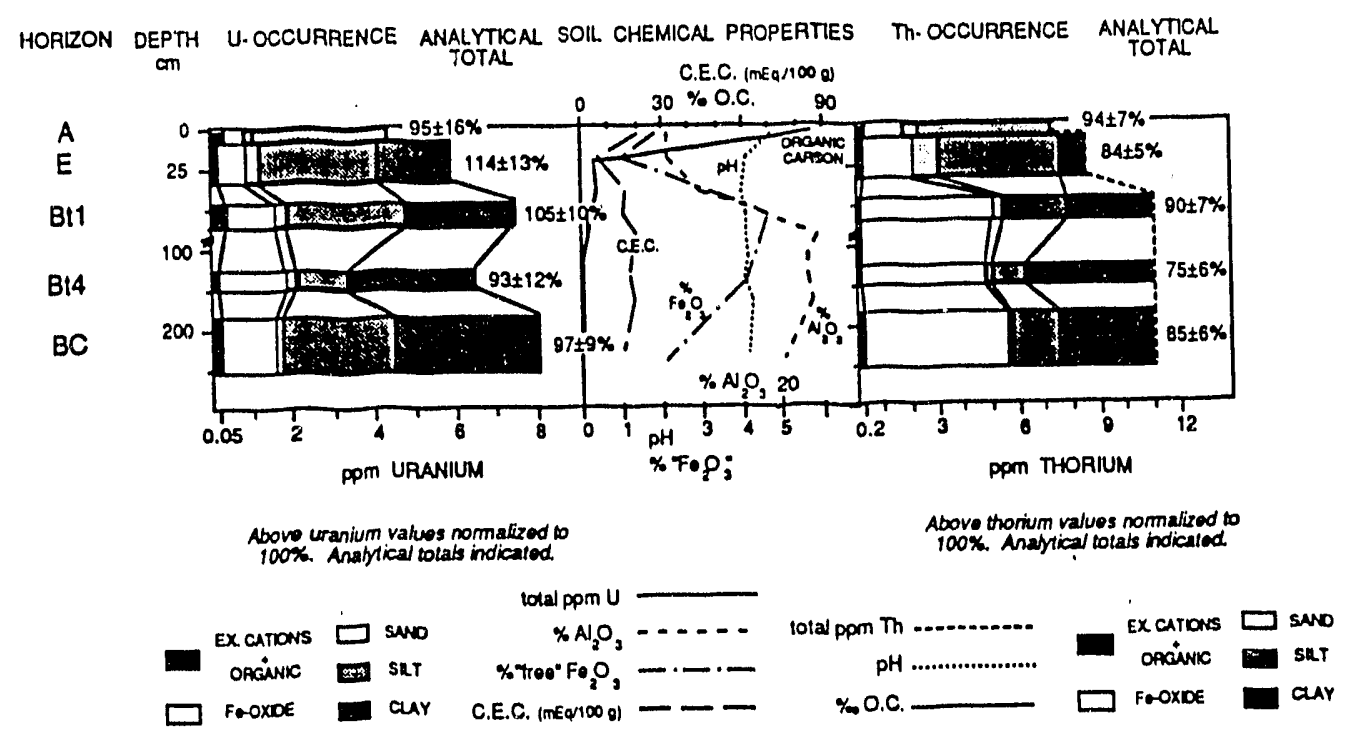

1. Form of $U$. Th and other soil properties vs. depth in a welll-drainod, dolostone-derived soil at stie 14-80. Abbreviations: O.C. - organic

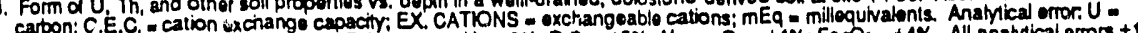

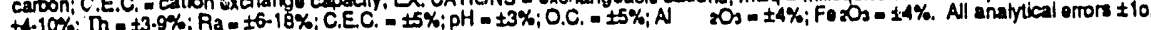

Figure 3. Concentration and form of $U$ and $T h$ in soil profiles at site $\mathrm{TN}-1$ (top) and 14-80 (bottom). 


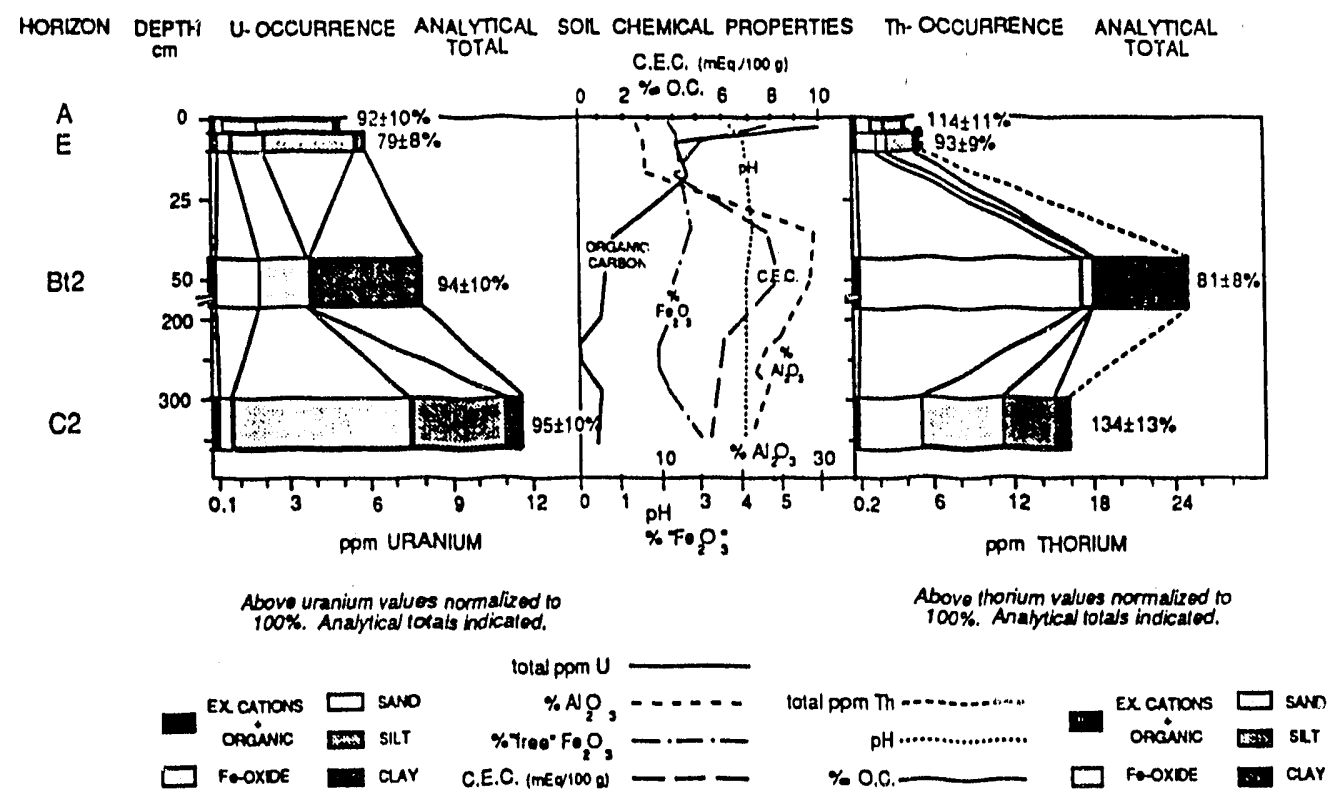

Form of uranium, thorium, and soil chemical propertles in a grantio-dertved soll at sthe NC.1. Note $4 X$ scalo at begining of uranium, thorium. and depth scakes. Abbreviations: O.C. organic carton; C.E.C. - cation exchange capacily; mEq - milliequivalonts; EX.

HORIZON DEPTH U.OCCURRENCE ANALYTICAL SOL CHEMICAL PAOPERTIES Th. OCCURAENCE ANALYTICAL

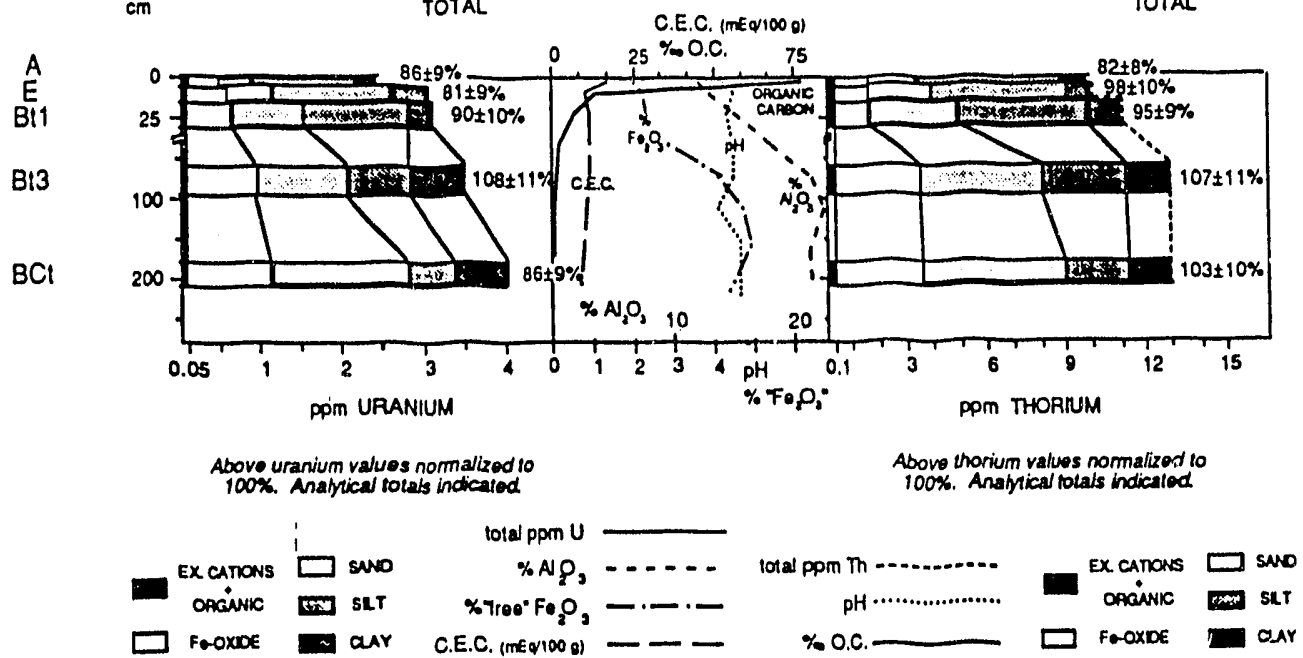

Form of uranium, thorium, and other soil properties in a shale-dertved sol at site 6-10. Nute $2 x$ scale at begining od depth, uranium, exchangeable catinns. Anahnical orror: $U- \pm 3-8 \% ;$ th $- \pm 3-8 \%$; soil propontios $= \pm 5 \%$. All anal vical orrors quoled a \pm 10 .

Figure 4. Concentration and form of $U$ and $T h$ in soll profiles at site NC-1 (top) and 6-10 (bottom). 


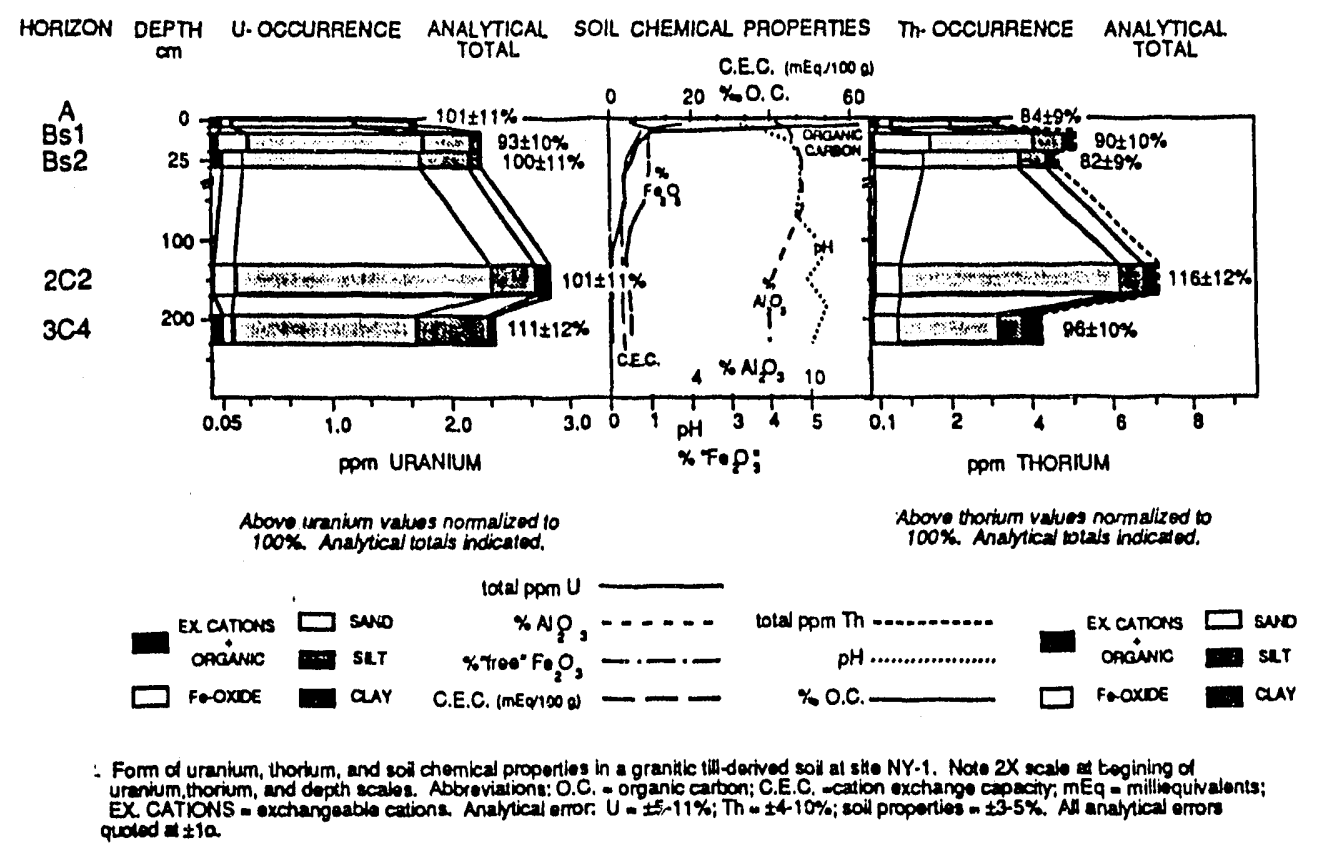

HORIZON DEPTH U. OCCURRENCE ANALYTICAL SOR CHEMICAL PROPERTIES TH. OCCURRENCE ANALYTILAL
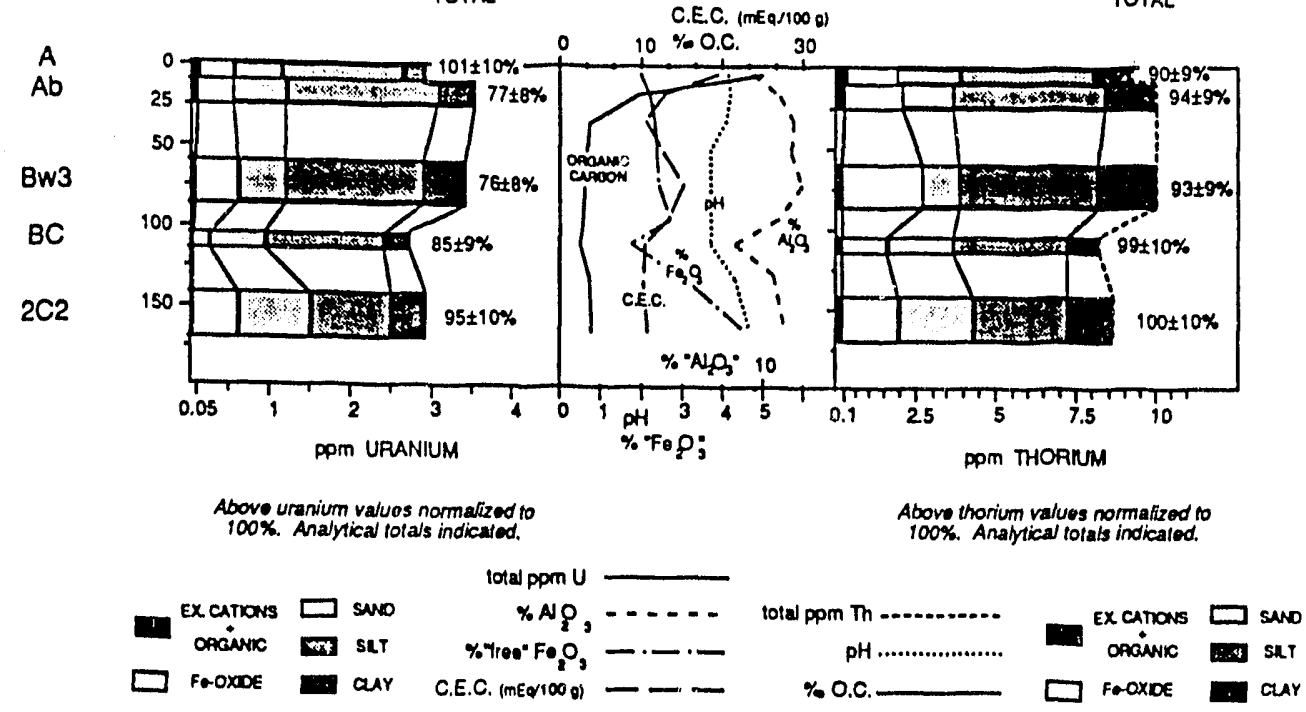

Form of uranium, thortum, and other soil properties vs. depth in an altuvial shale-derived soil at site 14-84. Note $2 x$ scale at begining Od uranium and thorium scales. Abbreviations: O.C. - orpanic carboni C.E.C. - cexion exchange capacty; mEq - millioguivalonts;

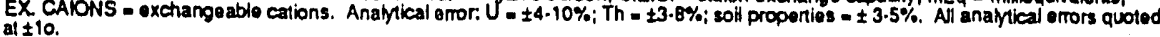

Figure 5. Concentration and form of $\mathrm{U}$ and $\mathrm{Th}$ in soil profiles at sites $N Y-1$ (top) and 14-84 (bottom). These two sites have post-glacial soils. 


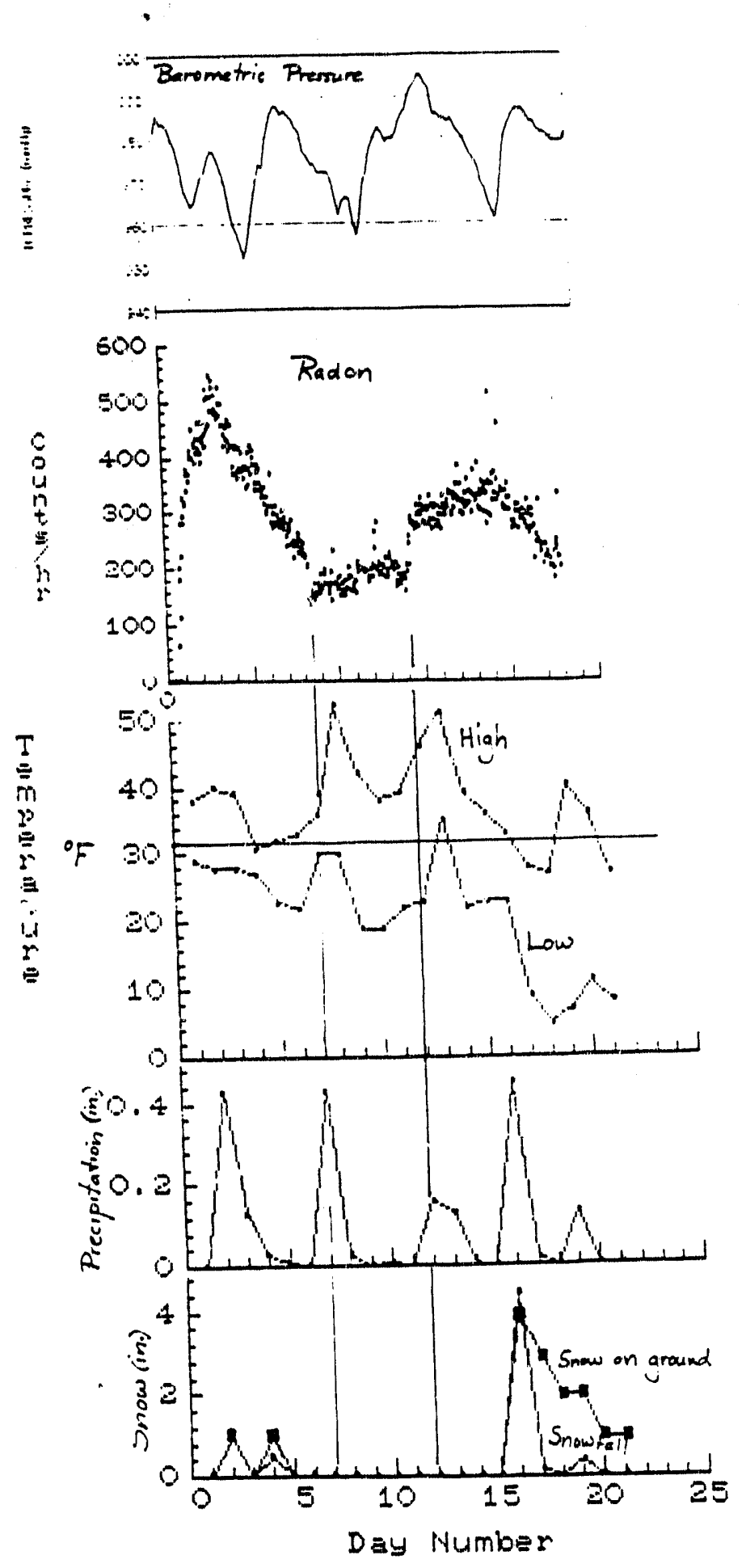

Figure 6. Radon and weather variables for the period Dec. 14, 1990 to Jan. 3, 1991 at site $14-80,60 \mathrm{~cm}$ depth, based on an AlphaNuclear surface barrier detector. The vertical lines at 7 and 12 days mark the abrupt changes in the radon values, which correlate with days of precipitation and melting of snow. Essentially no barometric effect is evident. 


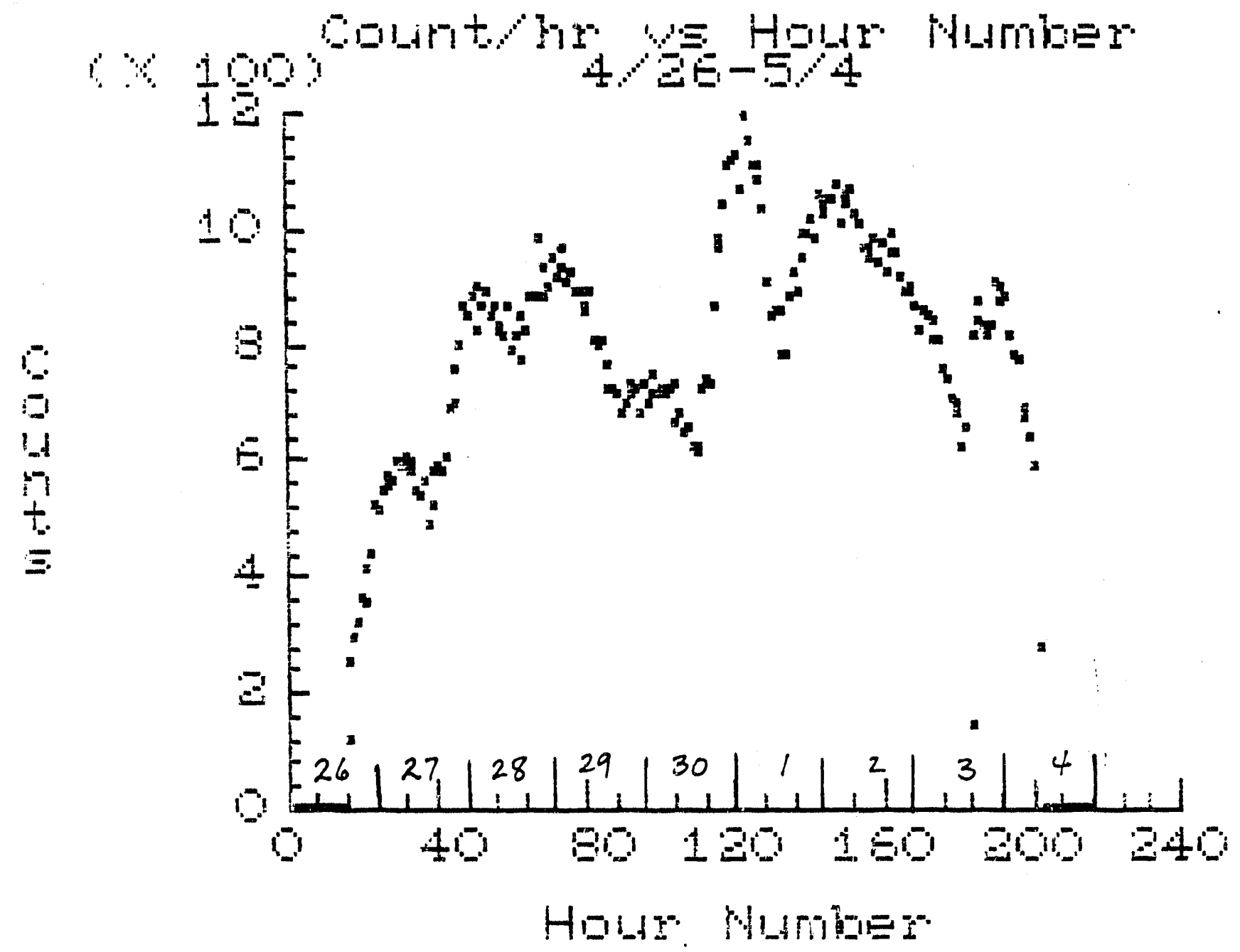

Eigure 7. Radon values (counts/hr) for surface barrier detector (Alphanuclear type) at site $14-80,60 \mathrm{~cm}$ depth for the period Apr. 26 to May 4, 1991. The values range widely, and a distinct diumal patsern is observed, with the peaks in early morning and the lows near midday. 
$\| \mathbf{L}, \ldots$
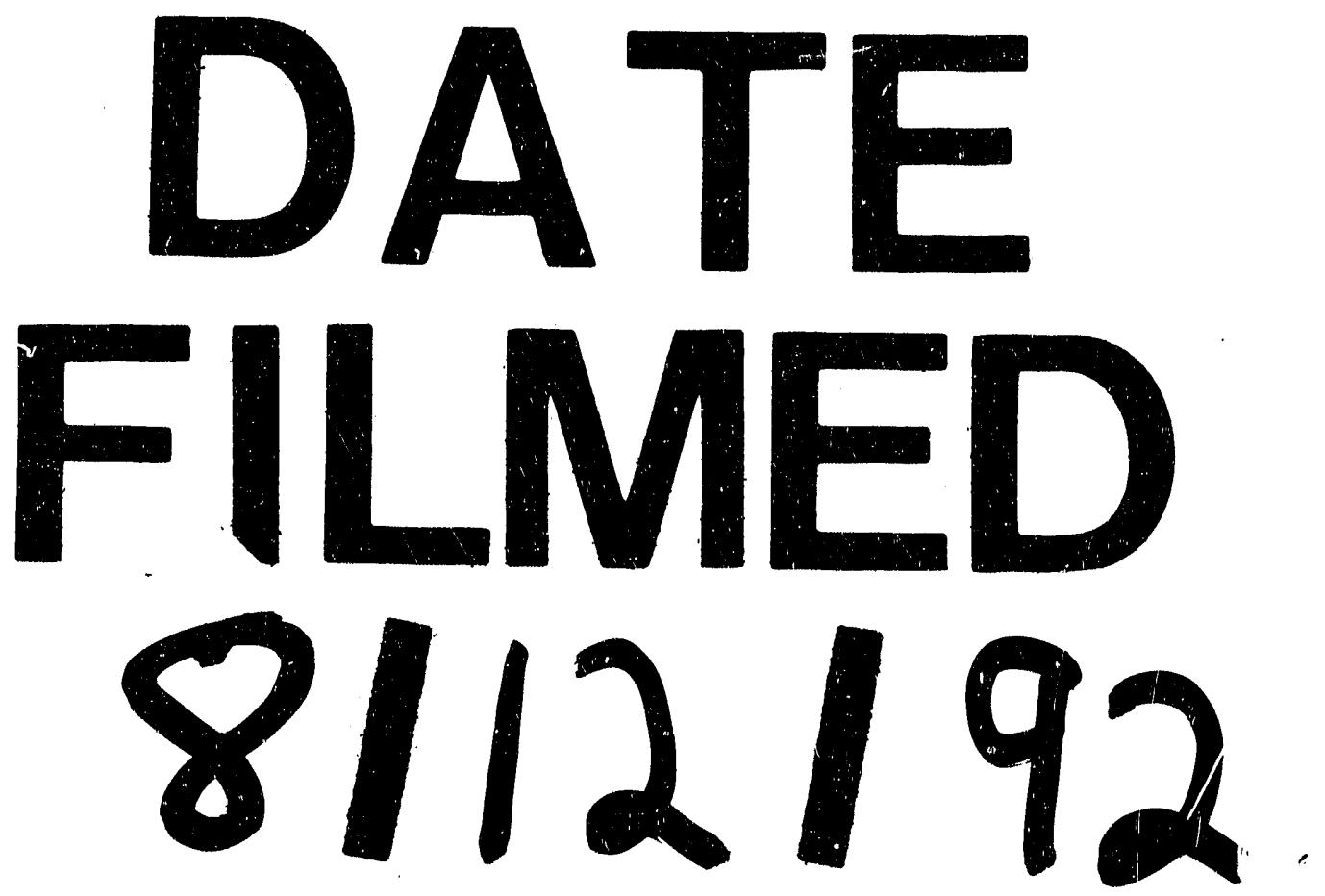


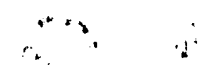

